\title{
Populism and the Return of the "Paranoid Style": Some Evidence and a Simple Model of Demand for Incompetence as Insurance against Elite Betrayal
}

\section{Citation}

Di Tella, Rafael, and Julio J. Rotemberg. "Populism and the Return of the 'Paranoid Style': Some Evidence and a Simple Model of Demand for Incompetence as Insurance against Elite Betrayal." Harvard Business School Working Paper, No. 17-056, December 2016.

\section{Permanent link}

http://nrs.harvard.edu/urn-3:HUL.InstRepos:30011593

\section{Terms of Use}

This article was downloaded from Harvard University's DASH repository, and is made available under the terms and conditions applicable to Open Access Policy Articles, as set forth at http:// nrs.harvard.edu/urn-3:HUL.InstRepos:dash.current.terms-of-use\#OAP

\section{Share Your Story}

The Harvard community has made this article openly available.

Please share how this access benefits you. Submit a story.

Accessibility 


$$
\text { H A R VAR D B US INESS SCHOOL }
$$

Populism and the Return of the 'Paranoid Style’: Some Evidence and a Simple Model of Demand for Incompetence as Insurance against Elite Betrayal

Rafael Di Tella Julio J. Rotemberg 


\title{
Populism and the Return of the 'Paranoid Style': Some Evidence and a Simple Model of Demand for Incompetence as Insurance against Elite Betrayal
}

\author{
Rafael Di Tella
}

Harvard Business School

Julio J. Rotemberg

Harvard Business School

Working Paper 17-056 


\title{
Populism and the Return of the "Paranoid Style": Some Evidence and a Simple Model of Demand for Incompetence as Insurance against Elite Betrayal
}

\author{
Rafael Di Tella \\ and \\ Julio J. Rotemberg ${ }^{*}$ \\ Harvard Business School, NBER, \\ CIfAR \\ Harvard Business School, NBER
}

First Draft: December 16, 2016

\begin{abstract}
We present a simple model of populism as the rejection of "disloyal" leaders. We show that adding the assumption that people are worse off when they experience low income as a result of leader betrayal (than when it is the result of bad luck) to a simple voter choice model yields a preference for incompetent leaders. These deliver worse material outcomes in general, but they reduce the feelings of betrayal during bad times. Some evidence consistent with our model is gathered from the Trump-Clinton 2016 election: on average, subjects primed with the importance of competence in policymaking decrease their support for Trump, the candidate who scores lower on competence in our survey. But two groups respond to the treatment with a large (between 5 and 7 percentage points) increase in their support for Donald Trump: those living in rural areas and those that are low educated, white and living in urban and suburban areas.
\end{abstract}

JEL Classification: F68, K42, D64.

Keywords: corruption, betrayal, populism, incompetence.

\footnotetext{
* Rafael Di Tella, Harvard Business School, Boston, MA 02163, US. rditella@hbs.edu Julio J. Rotemberg, Harvard Business School, Boston, MA 02163, US. jrotemberg@hbs.edu. We thank Alejandro Lagomarsino for helpful suggestions, as well as very generous help. We are grateful to Vincent Pons, Juan Dubra and Rawi Abdelal and seminar participants at Brandeis University for helpful comments and conversations.
} 
Alpargatas yes, books no. ${ }^{1}$

\section{Introduction}

It is not unusual for people disappointed with an election outcome to claim that it was the result of "populist" tendencies. ${ }^{2}$ The precise meaning of this varies, but standard elements include nationalism, redistributive politics and emotional speeches. It also often includes a peculiar dimension: disdain for competence. One example appeared during the 2016 US presidential election, where one of the candidates (Donald Trump) was declared to be incompetent by several observers, who then went on to attribute Trump's popularity to voter ignorance. ${ }^{3}$ This poses a puzzle for those typically impressed with individual rationality in other domains: why would voters sometimes choose the less competent candidate?

The canonical model in economics of competence in policymaking demonstrates that a less qualified candidate may receive the support of voters that are close to him/her on an ideological dimension (see Besley and Coate, 1997). But, in that model, incompetence reduces the appeal of a candidate whereas the appeal of populist leaders often appears to increase with perceptions of incompetence. Faced with this fact, some have conjectured that the incompetence may be seen as attractive because it is correlated with courage. ${ }^{4}$ While this is an extremely interesting idea, the exact mechanism through which voters in a democracy benefit from having (slightly blind) courageous leaders would probably benefit from further clarification.

In this spirit, we provide a formal model in which voters demand incompetence for well specified psychological reasons. Simultaneously, we provide empirical evidence showing that audiences that seem susceptible to persuasion by populism appear to increase their support for a relatively incompetent leader when they are primed to think about the role of competence in politics. Thus, targets of populism seem to have a particular strong aversion to voting for competent leaders.

We run a very short survey the week prior to the 2016 election. Half of the sample was asked three questions about the importance of competence. By design, these are ideologically neutral aspects of competence and most subjects agreed with the importance of competence for the design and implementation of policy. Given the fact that there is little

\footnotetext{
1 Alpargatas is Spanish for sandals of very low quality. Peronist slogan that started in a student/worker conflict of the 1940's but soon evolved to a slogan against (some forms of) competence.

2 See Paul Krugman, “The Populism Perplex”, The New York Times, November 25, 2016.

3 The statement by Robert Tuttle, a former official in the Reagan and Bush administrations is typical: "The Republican nominee for president has no government experience and has done nothing in his career to demonstrate that he is competent to be president". See Politico, October 8, 2016. See also, for example, Paul Krugman in The New York Times, “Trump's Delusions of Competence”, May 27, 2016, who concludes: "The truth is that the idea that Donald Trump, of all people, knows how to run the U.S. economy is ludicrous. But will voters ever recognize that truth?". A striking feature of that election was that voters, and even many of Trump's own supporters, shared the "experts"” assessment: exit polls revealed that $20 \%$ of those answering "No" to the question "Do you think Donald J. Trump has the temperament to serve effectively as president?" declared to have voted for him (whereas in the case of Hillary Clinton this was true for only $5 \%$ ). See for example, "Election 2016: Exit Polls", The New York Times, November 9, 2016 accessed at http://www.nytimes.com/interactive/2016/11/08/us/politics/election-exit-polls.html.
}

4 "His brazenness is not punished, but taken as evidence of his willingness to stand up to the elite". The Economist, September 10 th 2016. 
monetary consequence to answering one way or the other, and the fact that the "treatment" consists of simply reading something so short and non-controversial, we consider the evidence gathered as "minimal". Yet, the results are intriguing. Consistent with informal news reports, our subjects regard Clinton as more competent than Trump. We do not find a general result, confirming what pollsters and experts hypothesized before and after the election. ${ }^{5}$ There is no average effect of the "minimal treatment" on vote intentions. However, when we allow for effects that are specific to the sub-samples that have been singled out as receptive to populist rhetoric, the average effect on the rest of the sample is negative and significant in a Trump regression. This is consistent with a "standard" channel, whereby subjects primed about the importance of competence are less likely to vote for the candidate deemed less competent. In contrast, rural subjects and subjects that are white, have low educational attainment (less than two years of college) and live in urban and suburban areas react positively to the treatment.

We offer a simple model that can help interpret these findings. In a context where corruption is a concern, voters must choose between two otherwise identical candidates who differ in their competence for delivering material results to voters. The only departure from standard preferences is the assumption that people who experience low income feel worse when that is the outcome of an action of a politician who was previously trusted. This is consistent with evidence gathered in the lab whereby people prefer to be on low income as a result of luck than of other people's decisions (see, Bohnet and Zeckhauser, 2004).

Our approach is consistent with historical accounts of populist events. For example, in a celebrated essay Richard Hofstadter labels aspects of the populism style "paranoid", explaining the tight connection between politician incompetence and feelings of betrayal in generating populist demands:

Events since 1939 have given the contemporary right-wing paranoid a vast theater for his imagination, (...). Any historian of warfare knows that it is in good Part a comedy of errors and the Museum of incompetence; but if for every error and every act of incompetence one can substitute an act of treason, we can see how many points of fascinating interpretation are open to the paranoid imagination: treason in high places can be found at almost every turning - and in the end the real mystery, for one who reads the primary works of paranoid scholarship, is not how the United States has been brought to its present dangerous position, but how it has managed to survive at all. Richard Hofstadter, The Paranoid Style in American Politics, Page 25

Our model is related to a large literature that has focused on the competence of policy makers, starting with Rogoff's study of fiscal policy distortions by politicians that want to signal high ability (see Rogoff, 1990; see also Banks and Sundaram, 1993). Several papers have analyzed the ability of citizens entering politics, starting with Besley and Coate (1997). Carrillo and Mariotti (2003) study candidate selection by parties and show that parties can be excessively conservative, keeping mediocre incumbents for too long instead of experimenting with newcomers of uncertain quality. A natural question concerns the causes of low quality politicians, including the role of rewards from office in raising the quality of entering candidates (see, for example, Caselli and Morelli, 2004, Messner and Polbern 2004; on the role of threats, see Dal Bo and Di Tella, 2003). Several studies study candidate quality using education and pre-office income as indicators of competence (see, for example, Dal

5 See, "Multitude of Factors led to Republican's Surprise Win", The Wall Street Journal, Thursday, November 10, 2016. 
Bo, Dal Bo, and Snyder 2009; Besley and Reynal-Querol 2011; Galasso and Nannicini, 2011).

Our paper's focus on betrayal follows Bohnet, et al., (2004), who demonstrate in the lab that there is less risk taking when the agent of uncertainty is nature than when it is another person (see, also Bohnet, et al., 2008, for evidence on international differences as well as Bolton and Ockenfelds, 2010). This is also a theme in previous research in psychology. For example, Koehler and Gershoff (2003) find that people react more negatively to a bad action when it involves a violation of a duty (or promise). They find that, when choosing safety products, people prefer inferior options (in terms of risk exposure) to options that included an extremely small risk of betrayal but that choices were reversed when the betrayal risk was replaced by an equivalent risk not associated to betrayal. Finally, research in cognition has found that an experimental manipulation that is known to increase analytic processing reduces belief in conspiracy theories (see, Swami, et al, 2014). Obviously, work on betrayal is connected to the large literature on trust, (see for example, Knack and Keefer 1995; La Porta, et al. 1997; Guiso, Sapienza, and Zingales 2004; Aghion, et al. 2010).

Naturally, there is a lot of prior work on populism as an ideology, a strategy or a political style, in sociology, history and political science (for a recent review, see Gidron and Bonikowski, 2013). In economics, one strand of work emphasizes the role of social conflict and inequality (for an example with short-sighted voters, see Sachs, 1989). While it is tempting to call "populist" any policy that reduces growth, policies that maximize growth are only likely to be optimal for governments that care exclusively about "capitalists" (see, for example, Alesina and Rodrik, 1994). Another perspective, emerging partly from work describing macroeconomic populism, views it as including non-sustainable policies and beliefs about key elasticities that are non-standard amongst economists (see, for example, descriptions of the Peruvian experience in Dornbusch and Edwards, 1991). Acemoglu, Egorov and Sonin (2013) develop a model where politicians distort policies to signal to voters that they are not in the pockets of the elite. Politicians choose policies to the left of what the median voter prefers, which is interpreted as a form of populism. Checks and balances may not be useful because they may reduce the rents of the executive, making it cheaper for the elite to bribe (see Acemoglu, Robinson and Torvik, 2013). Similarly, Di Tella and MacCulloch (2009) study capture by the elite but focus on voters' evaluations of fairness and preference for left wing policies as a form of punishment.

In the next section we present a simple model that connects betrayal aversion, perceptions of corruption and competence in decision-making. Section III describes elements of the 2016 Presidential election in the US, emphasizing themes present in our model. Section IV describes the results from a short survey we run the week prior to this election. Section V concludes.

\section{A Simple Model of Paranoid Voters}

To explore the demand for incompetence, we start by capturing in a simple manner the idea that competent decision makers (DMs) have a higher likelihood of improving outcomes for voters at no cost to themselves. They do so by solving technical problems appropriately. In a more elaborate model, what these competent policymakers are able to do is to institute Pareto improving policies whose well-chosen transfers succeed in making everyone better off. Here, we simplify the analysis by letting all voters benefit equally. 
We first provide some broad intuition for the model's key parameters and for its broad mechanism of action. Afterwards, we present an asymmetric information model in which the space of contracts that DMs can write with voters is limited. In the equilibrium of this game, there are parameters for which the demand for incompetence is very strong.

The model contains two groups of agents, voters and potential decision makers. Individuals belong to one group or the other and all voters have identical tastes. In the first period, one voter chosen at random chooses one of the potential DMs to become leader. Leaders stay in office for one period. During this period, they have the opportunity to obtain information and to make one decision.

We now consider a relatively informal intuitive analysis. Competent DMs have a probability $p$ of coming up with a solution to a problem that voters did not necessarily regard as solvable. In other words, DMs acquisition of public office makes it possible for them to identify solutions to problems that voters face. DM's with a competence level $k$, have a probability $p k$ of doing so. If a DM solves a problem that voters had, voters' material payoffs rise to $H$. This exceeds the material payoffs $L$ that voters experience if none of their problems are solved. Thus, voters prefer DMs with higher values of $k$ if everything else is equal.

The competence of DM's is not the only determinant of whether DMs help the people who put them in office. Of similar order of importance is whether DM's prefer to help voters or prefer helping their personal friends (who, rather than being voters, belong to the group of potential DMs). In the extremely simplified setup we develop, there is a perennial conflict between the two: a DM has the opportunity to help her friends substantially only if she also has the ability to raise the material payoff of her voters to $H$. Moreover, the leader cannot help both voters and friends at the same time. It is only when the DM is lucky/competent enough to be able to solve a substantial problem faced by her voters that she has an opportunity to help her friends. If she does the latter, the voters get material payoffs of $L$, just as if the DM had not solved a voter problem in the first place.

Voters thus care a great deal about the probability, which we denote by $q$ that DMs will choose to help their friends when they could have helped voters instead. If DMs always prefer helping their friends to raising the material payoffs of voters, $q$ equals the probability that the DM knows the nature of the action that helps her friends when she figures out an action that helps voters. Alternatively, one can suppose that a DM always know the nature of the action that would benefit her friend (and leave voters with material benefits of $L$ ) whenever she knows how to increase the material payoffs of her voters to $H$. In this case, the probability $q$ is simply equal to the probability that the DM prefers to help her friends rather than the people who voted for her.

Regardless of the interpretation we give $q$, the expected material payoffs obtained by a voter from a DM are equal to

$$
L+p k(1-q)(H-L)
$$

Now suppose that, for simplicity, all DMs have the same values of $p$ and $q$. Voters can then all be expected to hope for the same election outcome, namely that a DM with the highest $k$ gets elected. This means that the voter who is chosen at random to cast the decisive ballot chooses a DM with the highest available $k$. 
This result hinges crucially on the assumption that voters care only about their material payoffs. However, political discourse is often marked by emotionally charged terms that fit poorly with the idea that voters care only about material payoffs. For example, it seems common for people to complain that politicians have "betrayed" them. ${ }^{6}$ The intuitive model we have been discussing has a natural moment in which it would be logical for voters to feel betrayed.

Suppose in particular, that voters knew that the DM who had been voted into office had an opportunity to increase the voters' material payoff to $H$, and that voters also knew (as a result of an investigation, say) that the DM chose to help her friends instead. Particularly if $q$ is interpreted as the probability that the DM will find herself preferring to help her friends rather than help those that put her into office, it seems reasonable for voters, at this point, to have a purely emotional loss in utility that is unrelated to the magnitude of the loss in material payoffs.

This is very much the perspective of Rotemberg (2008), where people have a minimal altruism that they expect others to have towards them, and react with anger when they feel the evidence suggests that people are not acting with an altruism level that exceeds this minimum. The evidence that people react with anger to observable acts that do not "look" altruistic is quite extensive including, for example, evidence from "road rage." See Rotemberg (2014). Indeed, people do not just care about outcomes, but they also care about how these outcomes came to be (see Rabin, 1993). In a clean demonstration of this effect Bohnet and Zeckhauser (2004) compare the decision to trust a stranger in a one-shot interaction with taking a risky bet, and find that trusting requires an additional risk premium to balance the costs of betrayal (see also Eckel and Wilson, 2004; Fehr, Urs Fischbacher, and Michael Kosfeld 2005). ${ }^{7}$ Bohnet et al (2008) finds very similar levels of betrayal aversion in comparable experiments in Brazil, China, Oman, Switzerland, and Turkey. Bohnet, et al (2010) study the role of different expectations of trust in different countries as an explanation for differences in willingness to pay to avoid trusting. Subjects in arab countries demanded a substantially higher minimum trustworthiness threshold before trusting than did American and Swiss subjects, well above the probability thresholds required to take risk in an analogous game where Nature determined the outcome. Cross regional differences in willingness to trust mainly came from differences in people's intolerance of betrayal (see Ashraf, et al 2006 for a comparison of reciprocity versus unconditional kindness in the determination of trust and trustworthiness; on expectations of trust see also Butler, Giuliano and Guiso, 2015, 2016).

In the simplest case of this model, voters cannot be expected to ever know whether they have been betrayed by DM's. In the case where they have been betrayed, their material payoffs equal $L$, the same as if the DM simply did not know the solution to any of their

\footnotetext{
6 Typing "betrayal" and "politician" in Google on 12/9/2016 leads to 526,000 results. The first of these articles asserts that "Betrayal is at the heart of US politics".

${ }^{7}$ Apparently, there is a biological basis for this type of trust: Kosfeld et al. (2005) give subjects a neuronal signal molecule that promote social behavior in animals and observe that they are more likely to accept the risk of betrayal, but does not change their evaluation of gambles involving random risk. Whitson and Galinsky (2008) conduct experiments demonstrating that uncertainty is connected to the perception of patterns in what is essentially a random outcome (including conspiracies). Conspiratorial beliefs have also been linked to being a member of a disadvantaged group (Abalkina-Paap et al., 1999 and Goertzel, 1994), and associated with the rejection of scientific findings (e.g., Lewandowsky, et al, 2013).
} 
problems. Still, they cannot help but to put some weight on the possibility that they will be betrayed at some point, since they know that some of the outcomes in which their material payoffs will equal $L$, will be the result of a DM choosing to favor her friends.

The resulting loss in utility is easiest to calculate if voters care about their expected utility $E U$, and this is computed by multiplying the probability of all three different outcomes (voters get $H$, voters get $L$ as a result of the DM not identifying the opportunity for improving material outcomes, and voters get $L$ as a result of being betrayed by the DM) times the utility of voters if they knew that they were in each of these three states. Suppose further that utility is simply equal to material payoffs in the first two of these states, while it equals $L-B$, in the third. The parameter $B$ thus captures the direct psychological loss of betrayal, and the use of this expected utility function implies that utility is linearly declining in the probability of this betrayal.

In the current model, the probability of betrayal is simply $p k q$. This implies that expected utility equals

$$
E U=L+p k(1-q)(H-L)-p k q B
$$

It follows that voters' $E U$ is strictly decreasing in $k$ if the following condition is satisfied.

$$
\frac{B}{H-L}>\frac{1-q}{q}
$$

Thus, for sufficiently large values of $B$ and $q$, voters strictly prefer more incompetent leaders to more competent ones. The intuition for this result is that, once $B$ and $q$ are high enough, the main effect of raising $k$ on $E U$ is to increase the subjective cost of betrayal, either because $q$ is high enough that people mostly expect betrayal or because the subjective cost of betrayal $B$ is high enough.

The result can be thought of as a political application of the theory of the second best (see, Lancaster and Lipsey, 1956): once leaders are not necessarily honest, it may be worth hiring those that are incompetent. Indeed, the abundance of traitors/corrupt leaders moves voters in the direction of electing incompetent leaders. To see this, notice that in the limit where $q$ equals one, the voter never receives the material payoff $H$ because he is always betrayed. As a result, he always prefers to make $k$ as low as possible. In particular,

$$
\lim _{q \rightarrow 1} \frac{\partial E U}{\partial k}=-p q B
$$

This intuitive analysis suggests that outcomes of the political process could be quite inefficient. In particular, the potential gains from having DMs that have access to information on how to help voters would be entirely dissipated if the equilibrium DM had a $k=0$. Moreover, in this case, the DM's friends do not benefit from the DM's knowledge either.

This raises the question of whether superior outcomes are possible. We now provide a game-theoretic structure based on asymmetric information and incomplete contracts that ensures that this outcome in which all information acquired by the DM is wasted is the only equilibrium. 
We let all potential DMs have the same $p$ and $q$, so they differ only in their $k$ 's. Some potential DMs are available whose $k$ equals zero. Between period 1 and 2 , after a potential DM becomes elected leader but before the leader makes any decisions, this particular DM acquires some "information" at no cost to herself. Crucially, this information is acquired only by the elected leader and not by any other members of the group of potential DMs.

We suppose in particular that the leader learns the values of two signals $s$ and $w$. Before these signals are realized, their $e x$ ante distribution is uniform between zero and one. If $s \leq k p$ , the DM also learns that, if she takes the specific action $b(s)$ in the second period (again at no cost to herself), the payoffs to voters equal $H$. Any other action, or any action when the realization of $s$ exceeds $k p$, ensures that voters receive a material payoff of $L{ }^{8}$

Notice that realizations of $s$ smaller than or equal to kp represent potentially good news for society because they imply that material payoffs of all voters can be increased. The realization of $w$, on the other hand, governs whether leaders will wish to help voters in this way. If $w \geq q$, the DM prefers to take action $b(s)$ over any other action. He thus wishes to help voters. If instead, $w \leq q$, the DM prefers an action that differs from $b(s)$, and which raises the payoffs of some of the leaders' friends. By assumption, all friends of leaders are members of the group of potential DMs. As in the previous informal analysis, leaders who can be expected to betray voters in this way with probability $\mu$, cause voters a direct expected psychological cost of $\mu \mathrm{B}$.

We suppose that no one except the leader directly observes either $s$ or $w$, and that leaders do not have a mechanism for directly revealing either of these signals. Therefore, there exists no feasible contract in which payments from voters to DMs depend on the realization of these signals. We make the same assumption regarding the material payoffs of voters, $H$ and $L$. DMs and voters are, in particular, unable to write contracts that make payments between these agents depend on the realized values of voters' material payoffs.'

If one accepts these limitations on feasible contracts, the only possible outcome in period 2 is for the DM to choose $b(s)$ when $s \leq k p$ and $w>q$. She chooses an action that favors her friends instead if $s \leq k p$ and $w<q$. The reason this is the only feasible allocation is that it is the one the DM favors and there is no scheme that allows voters to provide incentives to deviate from this allocation.

Notice that we have been quite vague concerning the feasibility of contracts between DMs and their friends. Empirically this reflects the lack of transparency that is one of the defining characteristics of these contracts. Theoretically, it turns out that the existence and breadth of allowable contracts of this type is reflected in the parameter $q$ already. If DMs are likely to help their friends because they are being bribed to do so, this raises $q$ in exactly the same way than does altruism of leaders for their friends.

\footnotetext{
${ }^{8}$ It might be objected that, when $k<1$, a DM with $p>s>k p$ could still take decisions "at random," and thereby occasionally set $b$ equal to $b(s)$, with the result that her voters obtain $H$. We have in mind a sufficiently large action space that this can be ignored. A stronger version of this result can presumably be obtained by supposing that DMs with $k<1$ are such bad decision makers that they are less likely than a purely random decision generator to come up with $b(s)$.

${ }^{9}$ In practice, the press seems to spend little time discussing such contracts, suggesting that they may indeed be uncommon.
} 
We now come to the first period. We demonstrate that, if condition (1) above is satisfied, the unique equilibrium wastes all information acquired by the DM. In other words, the resulting allocation is the same as if $\mathrm{p}$ were equal to zero for the elected DM. To see this, consider the voter that has been randomly selected to cast the decisive vote. This voter's $\mathrm{EU}$ is strictly decreasing in $\mathrm{k}$, so he chooses a $\mathrm{DM}$ with $\mathrm{k}=0$. As a result, the material payoffs of voters equal L every period and the DM never takes an action that benefits her friends. The outcome is indeed the same as if $\mathrm{p}=0$.

A final intuition for why paranoia can triumph in this case is that the probability of betrayal $\mu$ is equal to $p k q$ with the total expected cost of betrayal being equal to $\mu B$. This betrayal cost pushes towards a low $k$, since a low $k$ reduces the capacity of the DM to betray the voter.

The countervailing benefit of a higher $k$, is that the voter gets $H-L$ with probability $p k(1-q)$. Because the resulting expected gains depend somewhat differently on the parameters, it is straightforward to find conditions under which paranoia wins.

\section{The 2016 American Election}

The 2016 US election is a reasonable setting to study these questions, in part because one of the two candidates, Donald Trump, was consistently described as "populist", in what was an extremely partisan election. ${ }^{1011}$ It also involved several of the features emphasized above.

Competence: The two candidates were separated by the perception of a competence gap, favoring the least populist candidate (Hillary Clinton). There were many discussions in the media covering different dimensions of competence, including ability, temperament and experience. To some, this was part of a broader rejection of science by populists in the US and abroad. ${ }^{12}$ Many viewed it as one of the defining features of the election:

"The paramount question is whether a person exhibiting no qualification for the office -neither experience, nor preparation, nor personal character- is nonetheless to become president." Benjamin Friedman "On the Election III", New York Review of Books, November 10, 2016. ${ }^{13}$

\footnotetext{
10 On many measures, it was more polarized than ever before: in the 2016 presidential election over 1,700 counties the winner took the county by 20 percentage points or more (more votes were cast in these counties than in closely contested counties). In 2012 it was fewer than 1,100, while in 1988 it was fewer than 200. The Wall Street Journal, November 10, 2016.

${ }^{11}$ Charges of populism were levied against Hillary Clinton as well, but Trump was the overwhelming target of these accusations. See, for example, "Donald Trump, The Perfect Populist”, Politico Magazine, March 9, 2016. Part of the difficulty, of course, is the paradox of a billionaire acting as an "outsider" (perhaps because this gave him some freedom to act "unscripted").

12 Venezuela's Hugo Chavez claimed Simon Bolivar had been assassinated dismissing scientists' conclusions that liberation hero died of TB. He explained "The Venezuelan bourgeoisie continue to say that we are trying to change history. No. They changed it," in "Hugo Chávez claims Simon Bolívar was murdered not backed by science", The Guardian, 26 July, 2011. On Trump and climate change, see "Echoes of Galileo in the Populist Retreat from Reason", The Financial Times, December 7, 2016. Apparently, he explained "The concept of global warming was created by and for the Chinese in order to make U.S. manufacturing non-competitive."

13 See, also, Elizabeth Drew's entry in the same symposium: "Historians are going to have a hard time with this election. How to comprehend that someone manifestly unfit for the presidency won the nomination of one of the two major political parties and for some of the time was supported by almost as many of the voters as his
} 
Corruption: Trump's campaign focused on accusations of corruption against his rival, whom he named "crooked Hillary". In his speeches, he provided details. For example, in his speech of June 22, 2016 in New York City, he expanded

"She ran the State Department like her own personal hedge fund - doing favors for oppressive regimes, and many others, in exchange for cash. Then, when she left, she made \$21.6 million giving speeches to Wall Street banks and other special interests in less than 2 years - secret speeches that she does not want to reveal to the public. Together, she and Bill made $\$ 153$ million giving speeches to lobbyists, CEOs, and foreign governments in the years since 2001. They totally own her, and that will never change."

The central theme of his campaign was that the system was rigged. ${ }^{14}$ It was so successful that Trump soon claimed he was the first to use the word. ${ }^{15}$ By all accounts, these efforts were effective in framing the electoral choice for voters. ${ }^{16}$

Trump's status as a business tycoon with many interests abroad made him an unlikely leader to fight big business and foreign interests. Yet, he included specific proposals that appeared to contradict this perception. For example, he pledged to "renegotiate NAFTA" and dump the Trans Pacific Partnership ("it is a horrible deal"). And, on the same day AT\&T"s CEO announced "an $\$ 85$ billion wager ... 'that would turn the giant telephone company into one of the world's biggest media companies by swallowing Time Warner Inc.' Donald Trump told supporters in Gettysburg Pa., he would block the deal if elected. "Its too much concentration of power in the hands of too few" he said, calling the merger "an example of the power structure I am fighting." The company has one of the largest lobbying operations in Washington -spending \$16 million last year."

opponent?". See, also, Jennifer Rubin in The W ashington Post, "The GOP is picking an incompetent candidate", July 18, 2016. There were also many reports of Clinton's competence. One example is The Washington Post's endorsement of October 13, 2016, where she is described as "smart".

14 Apparently this was the advice of Roger Stone: "In a 13-page memo to Trump, Stone urged him to state that "the system is rigged against the citizens" and that he is the lone candidate "who cannot be bought." See "Donald Trump struggles to turn political fling into a durable campaign", The W ashington Post, August 9, 2015.

15 An article in FactCheck.org concluded "Our review of public statements suggests Trump borrowed the word from Sanders, who regularly has used the term "rigged" to describe the government systems that institutionalize income inequality. That has been a Sanders theme since day one of his campaign — long before Trump made the word a regular staple of his stump speeches. In fact, populist politicians have been using the term "rigged" for decades to describe various government or political systems - despite Trump's claim that a couple "political pros" told him that he was a trailblazer in using the word "rigged." Robert Farley, "Trump's 'Rigged' Claim”, in The Wire, July 12, 2016

16 After the election a standard conclusions was that her campaign was "dogged by scandal over her use of a private email server, paid speeches to Wall Street and accusations that she used the state department for a 'pay to play' scheme related to the charitable Clinton Foundation". See "Outsider has last laugh by tapping into voter disdain", in The Financial Times, November 10, 2016.

${ }^{17}$ See "Donald Trump vs. AT\&T: A Signal Test of How Business Will Fare in New Washington", The Wall Street Journal, November 16, 2016. 
Coherence: Finally, our model suggests populism is a coherent story connecting actions to outcomes rather than an instinctive emotional reaction without much order. ${ }^{18}$ Part of the Trump campaign focused on providing an interpretation of recent economic woes in America based on the existence of corruption. In the New York speech of June 22, 2016, Trump focused on Clinton's personal corruption (see above) and explained

"Because it's not just the political system that's rigged. It's the whole economy. It's rigged by big donors who want to keep down wages. It's rigged by big businesses who want to leave our country, fire our workers, and sell their products back into the U.S. with absolutely no consequences for them. It's rigged by bureaucrats who are trapping kids in failing schools. It's rigged against you, the American people.”

If anything, Trump's interpretation (and our approach), where betrayal has such a large effect on outcomes, provides too much order. Hofstadter pointed out the paradox:

"It is nothing if not coherent -in fact, the paranoid mentality is far more coherent than the real world, since it leaves no room for mistakes, failures, or ambiguities. It is, if not wholly rational, at least intensely rationalistic; it believes that It is up against an enemy who is as infallibly rational as he is totally evil, and it seeks to match is imputed total competence with its own, leaving nothing unexplained and comprehending all of reality in one overreaching, consistent theory." Page 37

\section{Minimal Evidence on Demand for Incompetence}

\section{IV.i. Survey design}

Our data was collected through Amazon's Mechanical Turk, an internet-based market for tasks. It opened on October 27, 2016 and was closed on November 3 (the election was on November 8, 2016). M-Turk was used to attract subjects by offering a small reward (1 dollar) for taking a brief survey ("The survey should take you less than 10 minutes") to "help us learn more about the relationship between politics, government and policy design in the context of the current election". When subjects started the survey they read a similar description including the information about us ("You are being asked to take part in a survey being done by a group of researchers from Harvard University"), and explaining that participation was voluntary and anonymous. We requested subjects that had prior HIT approval greater than $80 \%$ (i.e., subjects that at least $80 \%$ of their previous tasks had been approved by their "employers").

\footnotetext{
18 As one observer summarized it: "Most of the commentary about Trump has treated him as if he is a one-off, as someone who has emerged because of the peculiar coincidence of his larger-than-life self-absorption and the advent of social media platforms that encourage it. But the Trump-as-one-off argument begins to fall apart when we think about what else happened in politics this year. First of all, Trump is not alone. If he alone had emerged - if there were no Bernie Sanders, no Brexit, no crisis in the EU—it would be justifiable to pay attention only to his peculiarities and to the oddities of the moment. But with these other uprisings occurring this year, it's harder to dismiss Trump as a historical quirk." See, Joshua Mitchell, "Donald Trump Does Have Ideas -and We'd Better Pay Attention to Them”, Politico Magazine, September 15, 2016.
} 
The flow of the survey is simple: we first ask three basic questions (gender, age and a standard question on trust). Then the control group is asked the key outcome variable regarding vote intentions (named Trump). The rest of the survey follows.

Our "minimal" treatment was designed to prime subjects with the importance of competence in politics. It has three parts, each focused on different aspects of competence. The first part asserts that policy problems are difficult and "demonstrates" that ideology is not useful, by presenting two cases where the "best course of action" involved solutions that are on opposite sides of the ideological spectrum. It asks subjects the extent to which they agree on a $0-10$ scale with the following statements:

Nowadays problems in economic policy can be so complex that few people in government fully understand them. Sometimes, for example, the best course of action is to reduce regulations (as was the case with the entry of low-cost airlines), while at other times it would have been good to increase regulations (as was the case with financial products before the crisis).

The second question emphasizes the technical demands of some policy problems and how that allows politicians not to be captured by lobbies. It also asserts that good universities are a source of this "technical knowledge". It reads:

Politicians that understand technical matters can evaluate policies better and engage in a productive dialogue with industry and private interests. A good education, for example at a top university, is one of the ways a politician can gain such technical knowledge.

The third and final part of our "minimal treatment" includes relevant, practical experience as a source of knowledge. It reads:

Politicians can also improve their ability to find solutions to complex problems through practical experience, either work related or through participation in corporate boards.

Data emerging from such a simple survey have obvious limitations. On the other hand, several advantages (see Horton, Rand, and Zeckhauser 2011) have recently led several researchers to rely on this method for gathering data (see, for example, Kuziemko et al. 2015, Weinzierl 2014 and Saez and Stantcheva 2016). Several papers have studied the characteristics of M-Turk respondents and their usefulness for political research (see, Berinsky, Huber, and Lenz 2012, Mason and Suri 2012, and Huff and Tingley 2015).

The evidence we provide should be considered "minimal", for at least two reasons. First, the data we gather is from a short survey, administered on Amazon's M-Turk, where subjects give answers without much consequence. ${ }^{19}$ Second, the "treatment" that provides a source of independent variation consists in reading a very short passage (disguised as three questions) that is designed to prime subjects towards the idea that competence is helpful in politics.

\section{IV.ii. Data}

The survey was taken by 4,078 subjects. We collected data on the time spent by subjects on each of the windows that were presented during the survey. We note that several subjects

\footnotetext{
${ }^{19}$ As in most surveys of this type, payment is conditional on the task being approved, but subjects have an expectation that this will happen (and they are correct in this case).
} 
took less time than the minimum amount of time required for reading the questions (for example, two subjects took 14 seconds). To get potentially meaningful answers we consider only individuals that took at least 90 seconds to complete the survey (not considering the time spent in the treatment window). Second, among these individuals we consider only those who spent at least 3 seconds looking at the treatment window (this last condition doesn't apply to individuals assigned to the control group). We also introduce three other restrictions: we do not consider subjects that are under age, those answering that they will not vote and those that answer the third option ("I prefer to provide my own answer") in the gender question (question number 1). ${ }^{20} \mathrm{After}$ eliminating two other subjects who declared to live outside the US, the total number of observations is 3,532.

Table A presents the data summarized across treatments. It shows that, at least with respect to observables, the data are balanced across treatments, suggesting a successful randomization.

\section{IV. iii. Basic Characteristics of the Two Candidates}

Of course, people's average opinions can differ from the anecdotal evidence offered as context in section III. ${ }^{21}$ Thus, it is important to study the basic characteristics of the two candidates in our sample.

Competence: Table B presents evidence from four different questions using data from the untreated sub-sample. Column (1) reports the results using the question

\footnotetext{
In the current US election, Hillary Clinton stands out for her work ethic and for her attention to detail. She has a law degree from an elite institution (Yale University), she has launched many social initiatives since entering politics (such as the Arkansas Advocates Children and Families) and she has learned how real business works (for example, by serving on several corporate boards).

One advocate explained: "Even Hillary Clinton's sharpest critics will concede that she is exceptionally well-informed. Unusually for a presidential candidate, she's spent a lot of time in what were in effect staff jobs rather than principal jobs — roles in which knowing what she's talking about was a key part of the position."

Do you agree with this?
}

Almost $28 \%$ of the sample chooses numbers suggesting they disagree (below 5), whereas $67 \%$ choose numbers above 5 . The next three columns use questions where subjects have to decide if a particular description better fits Trump or Clinton. Column (2) reveals that 40\% of subjects report Trump is more "elitist, out of touch" than Clinton, whereas only $26 \%$ think this description is more applicable to Clinton. There are basically no differences in terms of how "popular, in synch with most Americans" both candidates are. There are large differences in the third category: $65 \%$ of subjects report that the phrase "Understands details of policies and how

\footnotetext{
20 The minimum number of seconds for which the frequency of subjects is 10 or more is 84 . Results are robust to other sample definitions, including using only subjects that took more than 120 seconds (the main change is weaker results in Table 1). They are also robust to excluding a small group of subjects that took 4 standard deviations more than the mean. In our sample of 3,532 subjects, the mean number of seconds spent answering the survey is 230 (std. deviation=240).

${ }^{21}$ Many have struggled to explain the origin of Trump's appeal. "Asked to choose one reason for their vote for Mr. Trump, none comes up with the same one." See "Diverse voices share yearnings for change", The Financial Times, Thursday November 10, 2016.
} 
to implement them" applies more to Clinton than to Trump, whereas only $12 \%$ report the opposite. This suggests that Clinton is clearly seen as more "competent" than Trump in our sample of untreated subjects.

Corruption: Table $\mathrm{C}$ focuses on perceptions of corruption, again using only the part of the sample that was not treated. It shows that subjects declaring to vote for Trump also think there is more corruption in the country. The exact question is

"How much corruption do you think there is in US politics? For example, if you take 10 politicians, how many do you think are corrupt?" Answers are on a slide, with 0 out o10 on the left-end and $10 / 10$ on the right-end.

The difference is large: Trump voters think that 7.80 out of 10 politicians in the US are corrupt while Clinton voters only think there are only 6.37. Interestingly, perceptions of corruption increase (monotonically) as the intensity of preference for Trump goes up. Subjects that don't know who they will vote, or are not going to vote, perceive corruption to be most widespread.

We also include in Table $C$ the answers to a question on the importance of being near people that keep their word. When we combine the Vote Trump and Leaning Trump categories (and the same for Clinton), there is evidence that Trump supporters regard keeping one's word a more important characteristic than Clinton supporters, but the evidence is not as strong as in the case of corruption.

\section{IV. iv. Main Regression Results}

To the extent that the "treatment" primes subjects about the importance of competence in politics, the treatment might be expected to increase the support for Clinton, who is seen as especially competent. This can be termed the "standard channel": if we have a candidate that is seen to excel in one attribute and success becomes more tied to this attribute, one would expect the attractiveness of that candidate to increase. Thus, a simple empirical test is to see if the treatment increases the support for Clinton. Our model suggests an alternative: in a context where corruption is important, treated subjects might want to increase their demand for the less competent candidate (Trump). Of course, subjects may simply disagree that something called competence exists and treat it as a partisan construct. In this case they may react negatively to the priming (because they will consider it an attempt to cheat) and also increase the support for the less competent candidate after being treated.

Table 1 presents our results using as the dependent variable Trump, a dummy equal to 1 if the subject will vote for or is leaning towards Trump, and zero otherwise. We note that just over $37 \%$ of our sample will vote/lean Trump, $49 \%$ vote/lean Clinton while a little over 13\% don't know. Column (1) reports the results of regressing Trump on our treatment showing an insignificant effect. In the rest of the paper we focus on specific groups that have been indicated as particularly susceptible to populist tendencies. Although support for Trump proved difficult to predict, ${ }^{22}$ those living in rural areas, and those with low

22 A typical description of Trump's voters is "A cross section of white America, educated and less so, affluent and less so, they do not fit into neat categories -apart from being overwhelmingly white." In "Diverse voices share yearnings for change", Financial Times, Thursday November 10, 2016. 
educational attainment living in the cities were considered his main voter base. ${ }^{23}$ Accordingly we pay particular attention to these two groups.

Column (2) adds Urban, a dummy equal to 1 if the subject described him/herself as "someone living in an urban area", as well as an interaction between this dummy and the treatment. Just over $27 \%$ of the sample (969 subjects) describe themselves as urban. The marginal effect on urban is negative and comfortably significant, but the interaction is insignificant. Column (3) repeats the exercise with people living in suburban areas (just over $48 \%$ of the sample). The direct effects are insignificant but the interaction term is negative. Although this effect is marginally significant (at the $5.2 \%$ level), it shows that suburban subjects that are primed about the difficulty of policymaking are less likely to vote for Trump, who is seen as the less qualified of the two candidates. This is consistent with what might be termed the "standard channel".

Column (4) includes the treatment and Rural, a dummy equal to 1 if the subject described $\mathrm{him} /$ herself as a "someone living in a rural area", and an interaction between Rural and Treatment. Over $24 \%$ of the sample identifies as Rural (859 out of 3,532 subjects). The marginal effect on Rural is positive and comfortably significant, confirming the view that Trump was more popular in rural areas (48\% vs 32\%, a gap in excess of 15 percentage points). The basic treatment effect is insignificant again (and negative) but interestingly, the treatment makes rural people more likely to say that they will vote Trump or that are leaning that way. The effect is only significant at the $7 \%$ level, but it is sizeable: rural people that were treated are 6 percentage points more likely to vote/lean Trump than untreated ones. ${ }^{24}$ Column (5) includes the two interactions (with Urban and Rural) with similar results.

Table 2 studies the role of education and race. Column (1) includes the treatment, an indication for low education and their interaction. Low education is taken to mean less than a 2-year college degree and there are 1,369 subjects reporting low education (almost 39\% of the sample). The three marginal effects are insignificant. The interaction between the treatment and low education is only significant at the $6 \%$, with a point estimate implying a sizeable effect.

To incorporate the racial element in Trump's support we can create a more restrictive category: those with low education and identifying themselves as White. The dummy Low Education, White is equal to 1 for 1,115 subjects. The results from column (2) suggest that this group is 9 percentage points more likely to support Trump. Again, those in this group that are "treated" are 6 percentage points more likely to support Trump, although this is significant only at the $10 \%$ level.

Column (3) is particularly interesting. It studies this effect outside of a rural setting (restricting the sample to urban and suburban residents). At 32\%, the base probability of voting/leaning Trump is lower in these areas. Within the smaller sample (of 2,563 non rural

\footnotetext{
23 See Greg Mankiw, “The Triumph of the Less Educated”, Saturday, November 12, 2016, or Paul Krugman, "Our Unknown Country", The New York Times, November 9, 2016. He states “There turn out to be a huge number of people — white people, living mainly in rural areas — who don't share at all our idea of what America is about. For them, it is about blood and soil, about traditional patriarchy and racial hierarchy."

24 Similar results obtain when we restrict the sample to subjects that spent at least two minutes taking the survey (instead of just 90 seconds). The size of the sample drops somewhat but, if anything, there is a very small increase in the point estimate of the effects of interest suggesting that our results are robust to eliminating from our sample the "fastest" subjects.
} 
subjects), 707 (or 27\%) are identified as both Low Education and White. The direct treatment effect is now negative and significant, suggesting that support for Trump on average falls when subjects are primed with the importance of competence in policy making. This is the "standard channel" now significant for the sample under consideration: priming on the importance of competence makes the competent candidate more attractive. In contrast, and consistent with our model, the coefficient on the interaction between the treatment and the dummy for Low education-White is positive and significant. The effect is quantitatively large: whites with less than 2 years of college that are treated are almost 7 percentage points more likely to vote for Trump than those non-treated.

Column (4) considers the full sample and includes indicators for the treatment and for both groups of interest: rural subjects on the one hand and whites living in urban and suburban areas that have low educational attainment. It shows that both groups increase their support for Trump when they are treated. The implied size of the estimated coefficients is quite large. Treated subjects in the base category (urban and suburban non-whites and whites with high education) were more than 5 percentage points less likely to vote for Trump than untreated subjects in the same group. In contrast, treated rural subjects were 5 percentage points more likely to vote for Trump than untreated rural subjects. Finally, urban and suburban low education whites that were treated were 7 percentage points more likely to vote for Trump relative to subjects in that same group but untreated.

What this shows is that it was an electoral mistake to emphasize Clinton's technical proficiency over Trump to motivate these groups of voters (as some of her supporters did; see footnote 1). A useful summary using the raw data is presented in Table 3.

A robustness exercise involves exploiting the three categories in our dependent variable (distinguishing between vote/lean Trump, vote/lean Clinton and "Don't know yet"). Very similar results obtain (and are available upon request).

\section{IV. v. Interpretation}

A common assumption about competence, as incorporated in our model in section II, is that it involves vertical differentiation, so that people of different ideological bends should agree that more of it is better. Under this "common assumption", our results provide evidence that reject what we call the "standard" model (without betrayal aversion) for some groups of voters (rural and low education whites). Instead, the evidence is consistent with a model where subjects treated with the importance of competence in policymaking understand that the chances of feeling betrayed are higher with a more competent policymaker. Thus, other things equal, they choose a less competent policymaker even if this implies a higher chance of being on a lower material payoff. The expectation under this assumption is that subjects would tend to agree with the idea that different forms of "competence" help in policymaking. In particular, rural and low education non-rural whites should be more likely to agree with our statements about the importance of "competence" for policymaking.

An alternative assumption is that there is no agreement regarding what competence means. For example, some groups may interpret competence as the ability to steal. In this case, subjects that are treated with the technical needs of policymaking associate it with more discretion that can be exploited by the more "competent". In other words, competence is 
either an ideological category or, if it is a non-ideological category, it has the opposite sign than what the confused elites allege (more of it is worse for everyone). ${ }^{25}$ The expectation under this "alternative assumption" is that subjects would tend to disagree with the idea that different forms of "competence" help in policymaking. In particular, rural and low education non-rural whites should be less likely to agree with our statements about the importance of "competence" for policymaking.

Table 4 presents some data looking only at the treated sample. It studies how the two categories that are seen as particularly receptive to populist rhetoric, namely rural subjects and low education non-rural whites, answer questions about competence. These questions are part of the treatment (so we focus only on treated subjects) and concern three dimensions of competence, which we call Complex, Technical and Practical.

It starts by affirming a key feature of competence, namely that not everyone has it ("Nowadays problems in economic policy can be so complex that few people in government fully understand them."). It then explicitly addresses the non-ideological dimension of competence. We create a variable (called Complex) with the extent to which they agree with the idea that complex problems in policy cannot be answered with ideology and that "few people in government fully understand them". Column (1) finds that rural subjects are less likely than those that are urban and sub-urban to agree with this statement. The average for the sample is 6.5 (std. dev. 1.86) so the effect represents a reduction equivalent to $11 \%$ of a standard deviation. In column (4) we observe a similar reaction by low education non-rural whites. The effect is similar (though significant only at the $11 \%$ level).

Column (2) studies Technical, a variable designed to capture the technical demands of understanding policy and link it to obtaining a degree at an elite school. Again rural subjects don't agree as much with this idea, significant at the 5.4\% level. The mean for Technical is 6.3 (std. dev. 2.17), so the difference with non-rural (urban and sub-urban) subjects is equivalent to $10 \%$ of a standard deviation. Column (4) shows that low education non-rural whites have the opposite reaction: they are more likely than other subjects to agree with the idea that there are technical demands that can be learned through formal education. The estimated effect, which is significant at the $1 \%$ level, involves an increase equivalent to almost $15 \%$ of a standard deviation in Technical.

Finally, column (3) studies Practical, which aims to capture the practical demands of policymaking and link it to obtaining practical experience through work or participation in corporate boards. The mean of Practical is 7.3 (std. dev. 1.74), so there seems to be more agreement on the benefits of practical than on technical knowledge in policymaking. The coefficient on Rural is insignificant but in column (6) the dummy on Low Education, White, Non-rural is positive and significant at the $2.3 \%$ level, implying an increase equivalent to $13 \%$ of a standard deviation in Practical.

The general conclusion emerging from these data favors the "common assumption": the average answer on each of the three dimensions of competence exceeds 5 (ranging from 6.3 to 7.3), indicating agreement with the idea that competence is helpful in the design of policy.

\footnotetext{
25 It may be paradoxical that the elite's are the ones that are confused. Stephen Bannon, an adviser to Donald Trump, had a radio show that catered to "those 'low-information' citizens who are mocked and ridiculed by their 'betters' - the clueless elites." See The Washington Post, November 20, 2016.
} 
There is of course substantial variation in answers (note that in Technical, one standard deviation takes you below 5).

Before turning to the results for specific groups, we note as background that Table B reveals that $65 \%$ of the overall sample of 3,532 subjects report that the phrase "Understands details of policies and how to implement them" applies to Clinton more than Trump. The 969 rural subjects are more skeptical of Clinton, but still 51\% of them are willing to accept that the phrase applies more to her than to Trump while only $18.3 \%$ of them think it applies more to Trump. Interestingly, 63\% of 707 low education non-rural whites answer that the phrase applies more to Clinton than to Trump, while $14.5 \%$ say it applies more to Trump than to Clinton.

Turning to the specific results, it is interesting to note that the answers given by rural subjects are, on average, more in line with the "alternative assumption" whereas low education non-rural whites are more in line with the "common assumption" about competence. This can be seen in the negative coefficients on Rural in the Complex and Technical regressions in columns (1-2) of Table 4. Rural subjects are less likely to agree with the ideas of competence summarized in Complex and Technical than the rest of the sample. In contrast, the evaluations of low education whites living in non-rural areas differ across dimensions. Whereas they are somewhat less likely than the rest of the sample to agree with competence as summarized by Complex (statistically insignificant), they are more likely to agree with competence as summarized by Technical (comfortably significant) and Practical (statistically significant) in columns (5-6) in Table 4. This group's reaction to competence is consistent with what we call the "common assumption" of competence as a good (implying that people of different ideological bends should agree that more of it is better). This group of subjects agrees that technical and practical competences are helpful in policy-making. And yet, when they are treated with the importance of these dimensions of competence, they are less inclined to vote for the more competent candidate. This evidence is inconsistent with the standard model (without betrayal aversion) and is consistent with our theory of populism as demand for incompetence.

\section{Conclusion}

The "stab in the back" was an image that became popular amongst right-wing German groups after the First World War as an explanation for Germany's predicament. It emphasized the idea that unpleasant groups (Jews, socialists, elite politicians) were responsible for engineering Germany's defeat (and for the terms of the surrender) even though the German army had not been defeated in the field. It singles out a key theme in populist discourse: betrayal. A second feature of populist rhetoric is disdain for scientific or technical competence, as traditionally embraced by elites. Is it possible that these two elements -betrayal and competence- are connected in a rational model?

The answer in this paper is yes. We present a simple theory of populism as demand for insurance against betrayal. Incompetent politicians deliver less material well-being to voters but are less capable of betraying their trust. Under the assumption that a certain level of income delivers less utility to voters when it is the result of another person's decision than when it is the result of bad luck (see, Bohnet and Zeckhauser, 2004), the model can yield a demand for incompetent leaders. The driving force of populism in our model is the lack of 
effective means of controlling potentially corrupt politicians. The only option available to voters that are betrayal-averse is to elect an incompetent politician who, at some material cost, will deliver fewer scenarios where a bad material outcome is the result of elite betrayal.

We then present "minimal" evidence consistent with these ideas. The week prior to the US 2016 election, we ask a sample of Americans (through Amazon's M-Turk) about their voting intentions. Prior to eliciting vote preferences we ask a subset of our sample their opinion about three statements explaining the "complex" nature of "technical" challenges to good policymaking, and about the increased importance of competence, gained both through education in elite institutions and through practical experience. This "minimal" intervention was designed to prime subjects about the importance of competence in policymaking. Our findings are intriguing. Subjects in general describe Clinton as more competent than Trump and Trump voters perceive a lot of corruption. There is no general effect of the "minimal" treatment. We then allow for a differential reaction by different demographic groups. In particular, we separate the reactions of those in rural areas, and whites, with low education living in non-rural areas. Our preferred specification reveals that the treatment priming subjects with the importance for technical competence in policymaking leads them, on average, to increase the support for the candidate deemed more competent by pundits and by the public in our sample (Hillary Clinton) by 5 percentage points. In contrast, treated rural subjects were almost 5 percentage points more likely to vote for Trump than untreated rural subjects. Finally, urban and suburban low education whites that were treated were 7 percentage points more likely to vote for Trump relative to subjects in that same group but untreated.

Our results suggest that populist politics has a competence dimension, and that it does not evoke similar reactions in all groups. It may thus have been a mistake to emphasize Clinton's technical competence with two groups of voters (rural and low educated whites). Interestingly, these are the two groups of voters that pundits declared to be susceptible to populist rhetoric. 
Table A: Our Sample, across Treatment and Control

\begin{tabular}{|c|c|c|c|c|}
\hline \multirow[b]{2}{*}{ Variable } & \multirow[b]{2}{*}{ Response } & \multicolumn{2}{|c|}{ Group } & \multirow[b]{2}{*}{ Different? } \\
\hline & & Control & Treated & \\
\hline \multirow{2}{*}{ Gender } & Male & $645(36.34 \%)$ & $644(36.65 \%)$ & \multirow{2}{*}{ No } \\
\hline & Female & $1,130(63.66 \%)$ & $1,113(63.35 \%)$ & \\
\hline Age & - & $36.34(11.67)$ & $36.53(11.65)$ & No \\
\hline Trust & - & $4.935(2.486)$ & $4.936(2.498)$ & $\mathrm{No}$ \\
\hline \multirow{5}{*}{ Race } & White & $1,460(82.25 \%)$ & $1,410(80.25 \%)$ & \multirow{5}{*}{ No } \\
\hline & Black & 187 (10.54\%) & $196(11.16 \%)$ & \\
\hline & Hispanic/Latino & $113(6.37 \%)$ & $111(6.32 \%)$ & \\
\hline & Asian & $61(3.44 \%)$ & $69(3.93 \%)$ & \\
\hline & Other race & $40(2.25 \%)$ & $52(2.96 \%)$ & \\
\hline \multirow{3}{*}{ Residence } & Urban & $427(24.06 \%)$ & $432(24.59 \%)$ & \multirow{3}{*}{ No } \\
\hline & Suburban & $863(48.62 \%)$ & $841(47.87 \%)$ & \\
\hline & Rural & $485(27.32 \%)$ & $484(27.55 \%)$ & \\
\hline \multirow{9}{*}{ Education } & $<=8$ th grade & $1(0.06 \%)$ & $0(0.00 \%)$ & \multirow{9}{*}{ No } \\
\hline & Some high school & $5(0.28 \%)$ & $12(0.68 \%)$ & \\
\hline & High School degree & $173(9.75 \%)$ & $169(9.62 \%)$ & \\
\hline & Some college & $512(28.85 \%)$ & $497(28.29 \%)$ & \\
\hline & 2-year college & $256(14.42 \%)$ & $248(14.11 \%)$ & \\
\hline & 4-year college & $587(33.07 \%)$ & $595(33.86 \%)$ & \\
\hline & Master's & $186(10.48 \%)$ & $173(9.85 \%)$ & \\
\hline & Doctoral & $19(1.07 \%)$ & $24(1.37 \%)$ & \\
\hline & Professional & $36(2.03 \%)$ & $39(2.22 \%)$ & \\
\hline \multirow{6}{*}{ Employment } & Full-time & $877(49.41 \%)$ & $863(49.12 \%)$ & \multirow{6}{*}{ No } \\
\hline & Part-time & $208(11.72 \%)$ & $200(11.38 \%)$ & \\
\hline & Self-employed & $235(13.24 \%)$ & $236(13.43 \%)$ & \\
\hline & Unemployed & $119(6.70 \%)$ & $117(6.66 \%)$ & \\
\hline & Student & $102(5.75 \%)$ & $104(5.92 \%)$ & \\
\hline & Not in labor force & $234(13.18 \%)$ & $237(13.49 \%)$ & \\
\hline \multirow{5}{*}{ Previous Vote } & Always & $926(52.17 \%)$ & $926(52.70 \%)$ & \multirow{5}{*}{ No } \\
\hline & Often & $391(22.03 \%)$ & $392(22.31 \%)$ & \\
\hline & Sometimes & $159(8.96 \%)$ & $162(9.22 \%)$ & \\
\hline & Few times & $87(4.90 \%)$ & $94(5.35 \%)$ & \\
\hline & Never & $212(11.94 \%)$ & $183(10.42 \%)$ & \\
\hline \multirow{6}{*}{ Previous Support } & Voted Rep & $271(15.27 \%)$ & $275(15.66 \%)$ & \multirow{6}{*}{ No } \\
\hline & Leaned Rep & $254(14.31 \%)$ & $273(15.55 \%)$ & \\
\hline & Switched & $392(22.08 \%)$ & $381(21.70 \%)$ & \\
\hline & Leaned Dem & $327(18.42 \%)$ & $322(18.34 \%)$ & \\
\hline & Voted Dem & $481(27.10 \%)$ & $447(25.46 \%)$ & \\
\hline & Don't know & $50(2.82 \%)$ & $58(3.30 \%)$ & \\
\hline
\end{tabular}

Notes. We present frequencies of responses and in parenthesis we show the percentage of people (within the treated or control group) that gave certain answer in a given question. For Age and Trust we present the mean value and the standard deviation in parenthesis instead. In the last column, if the p-value of the mean differences t-test (with respect to the control group) is higher than 0.1 we show 'No'. We considered the sample of people that spent at least a minute and a half in the survey (not considering the treatment window) and three seconds in the treatment window (when applicable), did not indicate that they would not vote and did not provide their own answer to the question on gender. Participants were allowed to choose several races (so total doesn't add to $100 \%$ when looking at race). 
Table B: Basic Candidate Characteristics: Competence

\begin{tabular}{|c|c|c|c|c|c|}
\hline \multirow{3}{*}{ Response } & \multirow{3}{*}{$\begin{array}{c}\text { (1) } \\
\text { Clinton } \\
\text { described as } \\
\text { well prepared, } \\
\text { Agree? }\end{array}$} & \multirow{3}{*}{ Response } & \multicolumn{3}{|c|}{$\begin{array}{l}\text { Please tell me which phrase you associate } \\
\text { with each candidate }\end{array}$} \\
\hline & & & (2) & (3) & (4) \\
\hline & & & Elitist & Popular & Understands \\
\hline $\begin{array}{l}0-4 \\
\text { (Disagree) }\end{array}$ & $\begin{array}{c}492 \\
(28 \%)\end{array}$ & $\begin{array}{l}\text { Describes Clinton } \\
\text { more than Trump }\end{array}$ & $465(26 \%)$ & $417(23 \%)$ & $1,162(65 \%)$ \\
\hline 5 & $\begin{array}{l}101 \\
(6 \%)\end{array}$ & $\begin{array}{l}\text { Describes Trump } \\
\text { more than Clinton }\end{array}$ & $718(40 \%)$ & $455(26 \%)$ & $218(12 \%)$ \\
\hline $\begin{array}{l}\text { 6-10 } \\
\text { (Agree) }\end{array}$ & $\begin{array}{l}1,182 \\
(67 \%)\end{array}$ & $\begin{array}{l}\text { Describes both of } \\
\text { them equally }\end{array}$ & $524(30 \%)$ & $160(9 \%)$ & $185(10 \%)$ \\
\hline \multirow{2}{*}{$\begin{array}{l}\text { Number of } \\
\text { Observations }\end{array}$} & \multirow{2}{*}{$\begin{array}{l}1,775 \\
(100 \%)\end{array}$} & $\begin{array}{l}\text { Doesn't describe } \\
\text { any of the two } \\
\text { candidates }\end{array}$ & $68(4 \%)$ & $743(42 \%)$ & $210(12 \%)$ \\
\hline & & $\begin{array}{l}\text { Number of } \\
\text { Observations }\end{array}$ & $\begin{array}{l}1,775 \\
(100 \%)\end{array}$ & $\begin{array}{c}1,775 \\
(100 \%)\end{array}$ & $\begin{array}{c}1,775 \\
(100 \%)\end{array}$ \\
\hline
\end{tabular}

Notes. We present frequencies of responses and in parenthesis we show the percentage of people (within the control group) that gave certain answer in a given question. Only the control sample is used. We considered the sample of people that spent at least a minute and a half in the survey, did not indicate that they would not vote and did not provide their own answer to the question on gender. Percentages don't add to 100 due to rounding.

Column (1) reports the distributions of answers for the question: "The support for Clinton has been summarized as follows:

In the current US election, Hillary Clinton stands out for her work ethic and for her attention to detail. She has a law degree from an elite institution (Yale University), she has launched many social initiatives since entering politics (such as the Arkansas Advocates Children and Families) and she has learned how real business works (for example, by serving on several corporate boards).

One advocate explained: "Even Hillary Clinton's sharpest critics will concede that she is exceptionally well-informed. Unusually for a presidential candidate, she's spent a lot of time in what were in effect staff jobs rather than principal jobs - roles in which knowing what she's talking about was a key part of the position."

Do you agree with this?

A slide from 0 to 10 is presented with cursor initially placed on 5, and with the words "Disagree completely" below the number 0 and "Agree completely" below 100 .

Columns (2-4) are the answers to "Please tell me which phrase you associate with each candidate:" Column (2): "Elitist, out of touch", Column (3): "Popular, in synch with most Americans", Column (4) "Understands details of policies and how to implement them". 
Table C: Basic Candidate Characteristics: Corruption

\begin{tabular}{|c|c|c|c|}
\hline & Observations & $\begin{array}{c}\text { (1) } \\
\text { Average Corruption }\end{array}$ & $\begin{array}{c}\text { (2) } \\
\text { Average Word }\end{array}$ \\
\hline Vote Clinton & 670 & $\begin{array}{c}6.37 \\
(2.34)\end{array}$ & $\begin{array}{c}8.54 \\
(1.44)\end{array}$ \\
\hline Leaning Clinton & 211 & $\begin{array}{l}7.16 \\
(2.18)\end{array}$ & $\begin{array}{l}8.69 \\
(1.36)\end{array}$ \\
\hline Leaning Trump & 174 & $\begin{array}{c}7.47 \\
(2.00)\end{array}$ & $\begin{array}{c}8.45 \\
(1.49)\end{array}$ \\
\hline Vote Trump & 488 & $\begin{array}{l}7.80 \\
(1.87)\end{array}$ & $\begin{array}{l}8.76 \\
(1.37)\end{array}$ \\
\hline Don't Know Yet & 232 & $\begin{array}{l}7.79 \\
(1.81)\end{array}$ & $\begin{array}{c}8.69 \\
(1.36)\end{array}$ \\
\hline Not Going to Vote* & 157 & $\begin{array}{c}7.96 \\
(1.90)\end{array}$ & $\begin{array}{c}8.68 \\
(1.51)\end{array}$ \\
\hline
\end{tabular}

Notes: Only the control sample is used. We considered the sample of people that spent at least a minute and a half in the survey, and did not provide their own answer to the question on gender. Percentages don't add to 100 due to rounding. ${ }^{*}$ Subjects in this category (Not Going to Vote) not included in our analysis.

Average Corruption is the average answer to the question "How much corruption do you think there is in US politics? For example, if you take 10 politicians, how many do you think are corrupt?" Answers are on a slide, with 0 out o10 on the left-end and 10/10 on the right-end.

Average Word is the average answer to the question "How much do you agree with the following statement? In life, it is truly important to be surrounded by people who keep their word. The answers are on a Slide that has the word "agree" below the number 0 and "disagree" below the number 10 ". 


\section{Table 1: Determinants of Trump Vote, for Different areas of Residence}

\begin{tabular}{|c|c|c|c|c|c|}
\hline & \multicolumn{5}{|c|}{ Dependent variable: Trump } \\
\hline & $(1)$ & $(2)$ & $(3)$ & $(4)$ & $(5)$ \\
\hline Treatment & $\begin{array}{c}0.0015 \\
(0.0163)\end{array}$ & $\begin{array}{l}-0.0004 \\
(0.0183)\end{array}$ & $\begin{array}{c}0.0306 \\
(0.0224)\end{array}$ & $\begin{array}{l}-0.0188 \\
(0.0197)\end{array}$ & $\begin{array}{l}-0.0313 \\
(0.0236)\end{array}$ \\
\hline Urban & & $\begin{array}{r}-0.1615^{* * *} \\
(0.0251)\end{array}$ & & & $\begin{array}{c}-0.1248^{* * *} \\
(0.0277)\end{array}$ \\
\hline Suburban & & & $\begin{array}{l}-0.0065 \\
(0.0230)\end{array}$ & & \\
\hline Rural & & & & $\begin{array}{c}0.1563^{* * *} \\
(0.0262)\end{array}$ & $\begin{array}{l}0.1142^{* * *} \\
(0.0278)\end{array}$ \\
\hline Interaction & & $\begin{array}{c}0.0139 \\
(0.0413)\end{array}$ & $\begin{array}{r}-0.0608^{*} \\
(0.0313)\end{array}$ & $\begin{array}{l}0.0676^{*} \\
(0.0374)\end{array}$ & $\begin{array}{l}0.0806^{* *} \\
(0.0400)\end{array}$ \\
\hline $\begin{array}{l}\text { Interaction } \mathrm{x} \\
\text { Urban }\end{array}$ & & & & & $\begin{array}{c}0.0455 \\
(0.0448)\end{array}$ \\
\hline Pseudo R ${ }^{2}$ & 0.0000 & 0.0150 & 0.0019 & 0.0236 & 0.0294 \\
\hline Observations & 3,532 & 3,532 & 3,532 & 3,532 & 3,532 \\
\hline
\end{tabular}

Notes. Marginal effects after logit. Robust standard errors in parenthesis. ${ }^{*},{ }^{* *},{ }^{* *}$ indicate statistical significance at the $10 \%, 5 \%$ and $1 \%$ levels, respectively. Regressions do not include additional controls. We considered the sample of people that spent at least a minute and a half in the survey (not considering the treatment window) and three seconds in the treatment window (when applicable), did not indicate that they would not vote and did not provide their own answer to the question on gender.

Dependent variable is Trump, a variable taking the value 1 if subject answered that he/she would vote for Donald Trump, or was leaning to vote for Donald Trump, and 0 otherwise. The mean for Trump is $37 \%$.

Treatment is a variable taking the value 1 if individual read "question" number 4 and 0 otherwise.

Interaction refers to a variable multiplying the Treatment and the other independent variable included in that column (unless specified).

Rural (Urban, Sub-urban) is a dummy equal to 1 if the subject lives in a rural (Urban, Sub-urban) area. 
Table 2: Determinants of Trump Vote, for Different Education Groups

\begin{tabular}{|c|c|c|c|c|}
\hline \multicolumn{5}{|c|}{ Dependent variable: Trump } \\
\hline & $(1)$ & $(2)$ & (3) & (4) \\
\hline Treatment & $\begin{array}{l}-0.0237 \\
(0.0210)\end{array}$ & $\begin{array}{l}-0.0196 \\
(0.0202)\end{array}$ & $\begin{array}{l}-0.0521^{* *} \\
(0.0221)\end{array}$ & $\begin{array}{r}-0.0558^{* *} \\
(0.0237)\end{array}$ \\
\hline Rural & & & & $\begin{array}{l}0.1669^{* * *} \\
(0.0277)\end{array}$ \\
\hline Low Education & $\begin{array}{c}0.0054 \\
(0.0236)\end{array}$ & & & \\
\hline $\begin{array}{l}\text { Low Education \& } \\
\text { White }\end{array}$ & & $\begin{array}{c}0.0934^{* * *} \\
(0.0251)\end{array}$ & $\begin{array}{c}0.0349 \\
(0.0292)\end{array}$ & \\
\hline Interaction & $\begin{array}{l}0.0651^{*} \\
(0.0345)\end{array}$ & $\begin{array}{l}0.0597^{*} \\
(0.0358)\end{array}$ & $\begin{array}{l}0.1193^{* * *} \\
(0.0444)\end{array}$ & $\begin{array}{l}0.1065^{* * *} \\
(0.0404)\end{array}$ \\
\hline $\begin{array}{l}\text { Low Education, White, } \\
\text { Non-rural }\end{array}$ & & & & $\begin{array}{c}0.0373 \\
(0.0313)\end{array}$ \\
\hline $\begin{array}{l}\text { Treated x Low } \\
\text { Education, White, } \\
\text { Non-rural }\end{array}$ & & & & $\begin{array}{l}0.1256^{* * *} \\
(0.0459)\end{array}$ \\
\hline Pseudo R ${ }^{2}$ & 0.0019 & 0.0112 & 0.0089 & 0.0296 \\
\hline Observations & 3,532 & 3,532 & 2,563 & 3,532 \\
\hline
\end{tabular}

Notes. Marginal effects after logit. Robust standard errors in parenthesis. *, **, *** indicate statistical significance at the $10 \%, 5 \%$ and $1 \%$ levels, respectively. Regressions do not include additional controls. We considered the sample of people that spent at least a minute and a half in the survey (not considering the treatment window) and three seconds in the treatment window (when applicable), did not indicate that they would not vote and did not provide their own answer to the question on gender.

Dependent variable is Trump, a variable taking the value 1 if subject answered that he/she would vote for Donald Trump, or was leaning to vote for Donald Trump, and 0 otherwise. The mean for Trump is $37 \%$, except in Column (3), which limits attention to the non-rural sample, and where it is $32 \%$.

Treatment is a variable taking the value 1 if individual read "question" number 3 and 0 otherwise.

Interaction refers to a variable multiplying the Treatment and the other independent variable included in that column.

Rural is a dummy equal to 1 if the subject lives in a rural area.

Low Education, White is a dummy equal to 1 if the subject is white and has less than 2 years of college.

Low Education, White, Non-rural is a dummy equal to 1 if the subject is white, has less than 2 years of college and lives in an urban or suburban area. 
Table 3: Summary of our Main Results

\begin{tabular}{llcc}
\hline \hline Groups & Treatment Status & Mean Trump & Observations \\
\hline \hline Rural & Treated & $53.7 \%$ & 484 \\
Rural & Non Treated & $48.7 \%$ & 485 \\
\hline Non-rural LEW & Treated & $42.2 \%$ & 353 \\
Non-rural LEW & Non Treated & $35.6 \%$ & 354 \\
\hline Non-rural Non-LEW & Treated & $27.1 \%$ & 920 \\
Non-rural Non-LEW & Non Treated & $32.1 \%$ & 936 \\
\hline Total & & $37.4 \%$ & 3,532 \\
\hline
\end{tabular}

Note: Trump is the percentage of subjects declaring to vote or lean towards voting Trump. Rural is the group living in rural areas. Non-rural LEW is the group of subjects that live in urban and suburban areas and that have low educational attainment (less than a 2 -year college degree) and are white. We considered the sample of people that spent at least a minute and a half in the survey (not considering the treatment window) and three seconds in the treatment window (when applicable), did not indicate that they would not vote and did not provide their own answer to the question on gender. 
Table 4: Different Forms of Competence

\begin{tabular}{l|c|c|c|c|c|c}
\hline \hline & $\begin{array}{c}(1) \\
\text { Complex }\end{array}$ & $\begin{array}{c}(2) \\
\text { Technical }\end{array}$ & $\begin{array}{c}(3) \\
\text { Practical }\end{array}$ & $\begin{array}{c}(4) \\
\text { Complex }\end{array}$ & $\begin{array}{c}(5) \\
\text { Technical }\end{array}$ & $\begin{array}{c}(6) \\
\text { Practical }\end{array}$ \\
\hline \hline & $-0.205^{* *}$ & $-0.228^{* *}$ & -0.025 & & & \\
Rural & $(0.100)$ & $(0.118)$ & $(0.093)$ & & & \\
White, Non-rural & & & & -0.136 & $0.315^{* * *}$ & $0.230^{* *}$ \\
& & & & $(0.112)$ & $(0.126)$ & $(0.103)$ \\
Constant & $6.533^{* * *}$ & $6.383^{* * *}$ & $7.333^{* * *}$ & $6.504^{* * *}$ & $6.257^{* * *}$ & $7.280^{* * *}$ \\
& $(0.052)$ & $(0.060)$ & $(0.049)$ & $(0.049)$ & $(0.058)$ & $(0.046)$ \\
& & & & & & \\
\hline $\mathrm{R}^{2}$ & 0.002 & 0.002 & 0.000 & 0.001 & 0.003 & 0.003 \\
\hline Observations & 1,757 & 1,757 & 1,757 & 1,757 & 1,757 & 1,757 \\
\hline
\end{tabular}

Notes OLS regressions using only the Treated sample. Robust standard errors in parenthesis. ${ }^{*},{ }^{* *},{ }^{* * *}$ indicate statistical significance at the $10 \%, 5 \%$ and $1 \%$ levels, respectively. Regressions do not include additional controls. We considered the sample of people that spent at least a minute and a half in the survey (not considering the treatment window) and three seconds in the treatment window, did not indicate that they would not vote and did not provide their own answer to the question on gender.

Dependent variable in column (1) and (4) is Complex, the answer to the question "Please tell me whether you agree with the following statements: (scale from 0 to 10 , with $0=$ Completely disagree, $10=$ Completely agree) Nowadays problems in economic policy can be so complex that few people in government fully understand them. Sometimes, for example, the best course of action is to reduce regulations (as was the case with the entry of low-cost airlines), while at other times it would have been good to increase regulations (as was the case with financial products before the crisis).

Dependent variable in column (2) and (5) is Technical, the answer to "Please tell me whether you agree with the following statements: (scale from 0 to 10 , with $0=$ Completely disagree, $10=$ Completely agree): Politicians that understand technical matters can evaluate policies better and engage in a productive dialogue with industry and private interests. A good education, for example at a top university, is one of the ways a politician can gain such technical knowledge."

Dependent variable in column (3) and (6) is Practical, the answer to "Please tell me whether you agree with the following statements: (scale from 0 to 10, with $0=$ Completely disagree, $10=$ Completely agree): Politicians can also improve their ability to find solutions to complex problems through practical experience, either work related or through participation in corporate boards."

Rural is a dummy equal to 1 if the subject lives in a rural area.

Low Education, White, Non-rural is a dummy equal to 1 if the subject is white, has less than 2 years of college and lives in an urban or suburban area. 


\section{References}

Abalakina-Paap, M., Stephan, W. G., Craig, T., \& Gregory, W. L. (1999). Beliefs in conspiracies. Political Psychology, 20, 637-647. doi: 10.1111/0162-895X.00160

Acemoglu, Daron, Georgy Egorov and Konstantin Sonin (2013) "A Political Theory of Populism", The Quarterly Journal of Economics, 771-805. doi:10.1093/qje/qjs077.

Acemoglu, Daron, Robinson, James A. and Ragnar Torvik, (2013) "Why Do Voters Dismantle Checks and Balances?," Review of Economic Studies, vol. 80(3), pages 845-875.

Aghion, P., Algan, Y., Cahuc, P., and A. Shleifer (2010). Regulation and distrust. The Quarterly Journal of Economics, 125(3), 1015-1049.

Alesina, Alberto, and Dani Rodrik (1994) "Distributive politics and economic growth" Quarterly Journal of Economics, 109, no. 2: 465-490.

Ashraf, N., Iris Bohnet,, and N. Piankov (2006) "Decomposing trust and trustworthiness", Experimental Economics, 9, 193-208.

Banks, J. and R.K. Sundaram (1993) "Adverse selection and moral hazard in a repeated elections model”, in W.A. Barnett, M.J. Inich, N.J Schofield (Eds.), Political Economy: Institutions, Competition and Representation, Cambridge University Press, Cambridge.

Berinsky, Adam J., Gregory A. Huber, and Gabriel S. Lenz (2012). "Evaluating Online Labor Markets for Experimental Research: Amazon.com's Mechanical Turk." Political Analysis 20 (3): 351-68. doi:10.1093/pan/mpr057.

Besley, T. and S. Coate, (1997), “An Economic Model of Representative Democracy”, Quarterly Journal of Economics, 112, 85-114.

Besley, T., Reynal-Querol, M., (2009). Do Democracies Select Better Leaders? Mimeo, LSE.

Bohnet, Iris, and Richard Zeckhauser (2004) “Trust, Risk and Betrayal." Journal of Economic Behavior and Organization, 55(4): 467-84.

Bohnet, Iris, Fiona Greig, Benedikt Herrmann, and Richard Zeckhauser (2008) "Betrayal Aversion : Evidence from Brazil, China, Oman, Switzerland, Turkey , and the United States." The American Economic Review 98 (1): 294-310.

Bohnet, Iris, Herrmann, B., and Richard Zeckhauser (2010). "Trust and the Reference Points for Trustworthiness in Gulf and Western Countries." Quarterly Journal of Economics, CXXV (2), 811-828.

Bolton, Gary E. and Axel Ockenfels (2010) "Betrayal Aversion: Evidence from Brazil, China, Oman, Switzerland, Turkey, and the United States: Comment", American Economic Review. Vol. 100, No. 1: Pages 628-633

Butler, J., Giuliano, P., and L. Guiso (2015). The Right Amount of Trust. Forthcoming Journal of the European Economic Association.

Butler, J., Giuliano, P., and L. Guiso (2016). Trust and Cheating. The Economic Journal, 126, 1703 1738.

Carillo, J and T Mariotti (2013) Electoral Competition and Politician Turnover", European Economic Review, 45, pp. 1-25

Caselli, Francesco and Massimo Morelli. (2004). "Bad politicians," Journal of Public Economics, 88: 75982. 
Dal Bo, Ernesto and Rafael Di Tella (2003) "Capture by Threat", Journal of Political Economy, vol. 111, no. $5,1123-54$.

Dal Bo, E., Dal Bo, P., Snyder, J., (2009) “Political Dynasties" Review of Economic Studies 76(1), 115-42.

Di Tella, Rafael and Robert MacCulloch (2009) "Why Doesn't Capital Flow to Poor Countries", Brookings Papers on Economic Activity, 2009.1: 285-321.

Dornbusch, Rudiger, and Sebastian Edwards, (1991) The Macroeconomics of Populism in Latin America, Chicago: University of Chicago Press.

Eckel, Catherine C., and Rick K. Wilson (2004) “Is Trust a Risky Decision?” Journal of Economic Behavior and Organization, 55(4): 447-65.

Fehr, Ernst, Urs Fischbacher, and Michael Kosfeld (2005) "Neuroeconomic Foundations of Trust and Social Preferences: Initial Evidence." American Economic Review, 95(2): 346-51.

Galasso, Vincenzo and Tommaso Nannicini (2011) "Competing on Good Politicians", American Political Science Review, 105, 1, 79-99.

Gidron, Noam and Bart Bonikowski (2013) "Varieties of Populism: Literature Review and Research Agenda", Weatherhead Center, working paper No. 13-0004.

Goertzel, T. (1994). Belief in conspiracy theories. Political Psychology, 15, 731-742.

Guiso, L., Sapienza, P., and L. Zingales (2004) "The role of social capital in financial development" The American Economic Review, 94(3), 526-556.

Hofstadter, Richard (1996) The paranoid style in American politics and other essays, Cambridge: Harvard University Press. Original essay was the Herbert Spencer lecture delivered at Oxford in November 1963.

Horton, John J., David G. Rand, and Richard J. Zeckhauser. (2011). “The Online Laboratory: Conducting Experiments in a Real Labor Market.” Experimental Economics 14 (3): 399-425. doi:10.1007/s10683-011-9273-9.

Huff, Connor, and Dustin Tingley. (2015). “'Who Are These people?' Evaluating the Demographic Characteristics and Political Preferences of MTurk Survey Respondents." Research \& Politics 2 (3): 1-12. doi:10.1177/2053168015604648.

Koehler, Jonathan J., and Andrew Gershoff. 2003. "Betrayal Aversion: When Agents of Protection Become Agents of Harm." Organizational Behavior and Human Decision Processes, 90(2): 244-61.

Kosfeld, Michael, Markus Heinrichs, Paul J. Zak, Urs Fischbacher, and Ernst Fehr (2005). "Oxytocin Increases Trust in Humans." Nature, 435(2): 673-76.

Knack, S., \& Keefer, P. (1995). Institutions and Economic Performance: Cross Country Tests Using Alternative Institutional Measures. Economics and Politics, 7(3), 207-227.

Kuziemko, Ilyana, Michael I. Norton, Emmanuel Saez, and Stefanie Stantcheva. (2015). "How Elastic Are Preferences for Redistribution? Evidence from Randomized Survey Experiments." American Economic Review 105 (4): 1478-1508. doi:10.1257/aer.20130360.

La Porta, R., Lopez-De-Silanes, F., Shleifer, A., and R. Vishny (1997). Trust in Large Organizations. AER Papers and Proceedings, 87(May), 333-338.

Lewandowsky, S., Oberauer, K., \& Gignac, G. E. (2013). NASA faked the moon landing Therefore, (climate) science is a hoax: An anatomy of the motivated rejection of science. Psychological Science, 24, 622-633. http://dx.doi.org/10.1177/0956797612457686.

Lipsey, R. G.; Lancaster, Kelvin (1956). "The General Theory of Second Best". Review of Economic Studies. 24 (1): 11-32. 
Mason, Winter, and Siddharth Suri. (2012). "Conducting Behavioral Research on Amazon's Mechanical Turk.” Behavior Research Methods 44 (1): 1-23. doi:10.3758/s13428-011-0124-6.

Messner, Matthias and Mattias Polborn (2004) "Paying Politicians", Journal of Public Economics, Volume 88, Issue 12, December, 2423-45.

Rabin, Matthew (1993) “Incorporating Fairness into Game Theory and Economics." American Economic Review, 83(5): 1281-1302.

Rotemberg, Julio J. (2008) "Minimally Acceptable Altruism and the Ultimatum Game." Journal of Economic Behavior \& Organization 66, nos. 3-4 (June). View Details

Rotemberg, Julio J. (2014) "Models of Caring, or Acting as if One Cared, About the Welfare of Others." Annual Review of Economics 6: 129-154.

Sachs, Jeffrey, (1989) "Social Conflict and Populist Policies in Latin America," NBER wp 2897.

Saez, Emmanuel, and Stefanie Stantcheva. (2016). "Generalized Social Marginal Welfare Weights for Optimal Tax Theory.” American Economic Review 106 (01): 24-45. doi:10.1257/aer.20141362.

Swami V., Voracek M., Stieger S., Tran U.S., Furnham A. (2014) “Analytic thinking reduces belief in conspiracy theories”, Cognition, 133 (3), pp. 572-585.

Weinzierl, Matthew. (2014). "The Promise of Positive Optimal Taxation: Normative Diversity and a Role for Equal Sacrifice.” Journal of Public Economics 118. Elsevier B.V.: 128-42. doi:10.1016/j.jpubeco.2014.06.012.

Whitson, J. A., and A. D. Galinsky, (2008). Lacking control increases illusory pattern perception. Science, 322, 115-117. doi: 10.1126/science. 1159845 


\section{Survey Instrument (M-Turk):}

October 27, 2016

\section{$\underline{\text { Survey on Politics and the Current Elections }}$}

You are being asked to take part in a survey being done by a group of researchers from Harvard University that will help us learn more about the relationship between politics, government and policy design in the context of the current election.

The survey should take you less than 10 minutes. Please select the link below to complete it. At the end of the survey, you will receive a code to paste into the box below to receive credit for taking our survey (you will receive $\$ 1$ for completing it).

If you have any questions, please contact us at rditella@hbs.edu. The survey is anonymous, and no one will be able to link your answers back to you. Participation is voluntary and you are free to stop participating at any time. Please do not include your name or other information that could be used to identify you. Please make sure to mark your Amazon Profile as private if you do not want it to be found from your Mechanical Turk Worker ID. Finally, we encourage you to screenshot or print this screen for your own records, so that you able to retain our contact information.

Survey link:

Code:

1. Gender
a. Male
b. Female
c. I'd prefer to supply my own response:

2. Age

3. Generally speaking, would you say that most people can be trusted or that you need to be very careful in dealing with people? $(0=$ Need to be very careful; $10=$ Most people can be trusted $)$

Treatment (half the sample)

4. Please tell me whether you agree with the following statements: (scale from 0 to 10, with $0=$ Completely disagree, $10=$ Completely agree; labels for Disagree and Agree were also shown)

4.1. Nowadays problems in economic policy can be so complex that few people in government fully understand them. Sometimes, for example, the best course of action is to reduce regulations (as was the case with the entry of low-cost airlines), while at other times it would have been good to increase regulations (as was the case with financial products before the crisis).

4.2. Politicians that understand technical matters can evaluate policies better and engage in a productive dialogue with industry and private interests. A good education, for example at a top university, is one of the ways a politician can gain such technical knowledge.

4.3. Politicians can also improve their ability to find solutions to complex problems through practical experience, either work related or through participation in corporate boards. 
5. In this election you are

Going to vote Clinton

Don't know but leaning Clinton

Don't know yet

Going to vote Trump

Don't know but leaning Trump

Not going to vote

6. Please tell me which phrase you associate with each candidate:

\begin{tabular}{|l|l|}
\hline Elitist, out of touch & $\begin{array}{l}\text { Describes Clinton more than Trump } \\
\text { Describes Trump more than Clinton } \\
\text { Describes both of them equally } \\
\text { Doesn't describe any of the two candidates }\end{array}$ \\
\hline Popular, in synch with most Americans & $\begin{array}{l}\text { Describes Clinton more than Trump } \\
\text { Describes Trump more than Clinton } \\
\text { Describes both of them equally } \\
\text { Doesn't describe any of the two candidates }\end{array}$ \\
\hline $\begin{array}{l}\text { Understands details of policies and how to } \\
\text { implement them }\end{array}$ & $\begin{array}{l}\text { Describes Clinton more than Trump } \\
\text { Describes Trump more than Clinton } \\
\text { Describes both of them equally } \\
\text { Doesn't describe any of the two candidates }\end{array}$ \\
\hline
\end{tabular}

7. How much do you agree with the following statement?

In life, it is truly important to be surrounded by people who keep their word

Slide Agree disagree

8. How much corruption do you think there is in US politics? For example, if you take 10 politicians, how many do you think are corrupt?

slide: 0 out o10 $10 / 10$

9. The support for Clinton has been summarized as follows:

In the current US election, Hillary Clinton stands out for her work ethic and for her attention to detail. She has a law degree from an elite institution (Yale University), she has launched many social initiatives since entering politics (such as the Arkansas Advocates Children and Families) and she has learned how real business works (for example, by serving on several corporate boards).

One advocate explained: "Even Hillary Clinton's sharpest critics will concede that she is exceptionally well-informed. Unusually for a presidential candidate, she's spent a lot of time in what were in effect staff jobs rather than principal jobs — roles in which knowing what she's talking about was a key part of the position."

Do you agree with this?

Slide completely disagree completely agree

10. Race (select all that apply)
a. White
b. Black 

c. Hispanic or Latino
d. Asian
e. Other

11. Which comes closest to describing you:

- Someone living in an urban center

- A suburbanite

- Someone living in a rural area

12. State where you were born

13. State where you currently reside

14. Which category best describes your highest level of education?
a. Eighth Grade or less
b. Some High School
c. High School degree/ GED
d. Some College
e. 2-year College Degree
f. 4-year College Degree
g. Master's Degree
h. Doctoral Degree
i. Professional Degree (JD, MD, MBA)

15. What is your current employment status?
a. Full-time employee
b. Part-time employee
c. Self-employed or small business owner
d. Unemployed and looking for work
e. Student
f. Not in labor force (for example: retired, or full-time parent)

16. In previous elections, did you usually vote?

\author{
Always voted \\ Often voted \\ Sometimes voted \\ Few times voted \\ Never voted \\ 17. Where did you typically stand? \\ Voted republican \\ Leaned republican \\ Switched depending on the election \\ Leaned democrat \\ Voted democrat \\ Don't know
}

